\title{
SHAKESPEARE RE-READ, RE-WRITTEN, RE-CONTEXTUALISED OR... RE-PLACED IN OPERA AND MUSICAL
}

\author{
ALINA BOTTEZ
}

University of Bucharest

\begin{abstract}
Shakespeare thrives not only in the theatre, but also through what Bolter and Grusin call remediation. This article analyses how opera and musical reread Elizabethan drama shifting from spoken to sung discourse and travelling transnationally, temporally and across genres. Its main approach is comparative and relies on the history of mentalities. Rereading is dictated by cultural context, the conventions of the lyrical theatre, social and political factors and reception. Gender is reread in Bellini's I Capuleti e i Montecchi and in Britten's A Midsummer Night's Dream, and religion - in Gounod's Roméo et Juliette and Bernstein's West Side Story. Cultural and historical barriers enjoin recontextualisation: the English, French and Welsh verbal fun in The Merry Wives is metamorphosed into Germ-Italian in Salieri's Vienna, while prayer is bowdlerised in Bentoiu's Hamlet written in communist Romania. Porter's Kiss Me, Kate rewrites The Taming of the Shrew in a post-modern musical avant la lettre featuring the cast of a theatre company on- and off-stage. However, operas such as Rossini's Otello or Thomas's Hamlet are shown to have almost replaced Shakespeare's initial message. The article emphasises the idea that operations of rereading and rewriting, in a musical context, significantly enrich the ample panoply of Shakespearean adaptations.
\end{abstract}

Keywords: Shakespeare, theatre, music, opera, musical theatre, adaptation, remediation, appropriation, translation

After more than four centuries since Shakespeare's death, we are all aware that the scope of the Bard's popularity has by far exceeded the boundaries of the theatre and of the printing press. Besides being quoted in everyday life, his lines appear as advertisements or mottoes for conferences, as opening lines for the Criminal Minds series or as film appropriations, such as the 1997 A Thousand Acres starring Jason Robards, Michelle Pfeiffer, Jessica Lange, Jennifer Jason Leigh and Colin Firth. An adaptation of the Pulitzer Prize-winning novel of the same name by Jane Smiley, the film is a reworking of William Shakespeare's 
King Lear telling the story of Larry and his three daughters - Ginny, Rose and Caroline - twentieth century Iowa versions of Goneril, Regan and Cordelia.

Besides cinema and television, various other media have made Shakespeare theirs through what Bolter and Grusin call 'remediation', and opera is among the veterans, the first Shakespeare adaptations into this medium going back to the seventeenth century. During the Victorian age, in the mid-nineteenth century, Guilbert and Sullivan laid the foundations of a musical theatre, which joined the opera in rereading Elizabethan drama while shifting from spoken to sung discourse and travelling transnationally, temporally and across genres. Rereading is dictated by the cultural context, the conventions of the lyrical theatre, by social and political factors, as well as reception.

Gender can be re-contextualised according to vocal traditions and mentalities. Thus, the early bel canto style pressed for flamboyant vocal prowess, creating the vocal "aberration" of what we nowadays call the countertenor, but which started as the barbarous practice of the castrati. Therefore, the audience was used to watching men act as heroes or lovers on stage, yet the voices that sprang forth from those men had a feminine timbre. As the fashion of the castrati faded away because of its cruelty to the talented young singers, the European opera audience was nevertheless left with the habit of hearing female-sounding voices emitted by male-looking characters. Therefore, later bel canto will replace the fashion of the castrati with that of what we might call vocal travesty: male roles started being interpreted by women, especially mezzosopranos, which takes us to the exact opposite of the all-male Elizabethan theatre company. A shocking example of this common bel canto practice is Bellini's I Capuleti e i Montecchi, where Romeo, the emblem of romantic male love par excellence, is interpreted by a mezzosoprano so that the youth of the character might be brought into bold relief. The effect of the female voice is hard to palate nowadays, in an age which strives for naturalness and true-to-life rendition in acting and stage direction. But at the beginning of the nineteenth century, the passage from the age of the castrati was seamless and the casting of a woman in a fervent lover's part was accepted without a second thought as part of a common convention that reread an earlier practice grown obsolete.

\section{****}

Gender becomes an even more poignant issue in the twentieth century. In 1960, at the beginning of the Sexual Revolution, homosexual composer Benjamin Britten writes his superb opera A Midsummer Night's Dream, while his lifelong partner Peter Pears helps him write the libretto. The opera makes underlying comments that bring the play well into contemporary England - not only through the visionary modernity of the music, but also through gender hints. Thus, the part of the fairy-king Oberon, the epitome of male power and 
even macho vanity in Shakespeare's play is written for a countertenor - a tribute to the Baroque that Britten adored. We can safely assume that the term "fairy" could not have been lost on them either. Alfred Deller, the interpreter of the part, had a voice that was weak in the high register. Therefore, Oberon almost never sings at the top of the alto range and forte at the same time. The result is a typically postmodern, self-ironic "translation" of Britten's homosexuality, since Oberon appears to be completely emasculated in the opera and, vocally, soft and weak, quite dominated by Tytania's ${ }^{1}$ virtuoso prowess. This type of timbre underminingly suggests that the traditional conception of "maleness" is open to reinterpretation. The contrast between the effeminate Fairy King and the maneating Fairy Queen who wears the trousers in the relationship creates a strong comic effect, which is primarily auditory, as when they sing together he can hardly be heard, while when they sing alternately, the volume discrepancy is hilarious and unflattering.

****

If gender can be rewritten according to the cultural context, so can religion. Historically, Elizabethan England was characterised by a confusing religious configuration, finely described by Greenblatt in his book - Will in the World. Shakespeare himself is known to have oscillated between elements of Catholic and Protestant faith, which is illustrated especially in Hamlet. However, a country such as Gounod's nineteenth century France rewrites the religious threat in the light of staunch Catholicism, wiping out all trace of blame from Friar Laurence's behaviour and lending him the aura of a luminous character.

$$
* * *
$$

In a cultural space such as Romania, however, Catholic and Protestant features are hardly relevant and Pascal Bentoiu's music will borrow Greek orthodox sonorities in Hamlet. But since the opera was written in 1969, the libretto is re-contextualised and the threat of communist censorship induces the composer and librettist to bowdlerise the prayer scene.

The most moving tool that he uses to translate Englishness into Romanianness is therefore not speech, but music. Even before the beginning of the text, the modal wordless a cappella choral Prologue bears a strong Byzantine influence (even if the chorus is mixed ${ }^{2}$ ), which immediately renders this Hamlet more eastern. In the original version, this chorus did not exist. But the composer felt that something was missing and added it in the guise of a prelude or overture, which announces that this Hamlet was born and bred in Greek

\footnotetext{
${ }^{1}$ Britten's spelling.

${ }^{2}$ Mixed choruses are formed of both male and female voices, while Byzantine music is traditionally written for male voices only. However, nowadays, this has changed and women are frequently included in Byzantine choirs.
} 
Orthodox churches, featuring the unison and bass drone as well as modern harmony. The minor mode and the mournful pace make it sound like a threnody, frequently used in Orthodox Easter music.

The concluding Epilogue, which is also a chorus, is accompanied by the orchestra and does have a text to go with the music: "A noble soul is dwindling. / Good night, sweet prince. / May the song of angels' wings / Eternally shroud thy rest" (Bentoiu 26, my translation). The libretto echoes Ophelia's lines "Good night, ladies; good night, sweet ladies; / good night, good night" (4.5.69-70). The collective character behaves like the ancient chorus in Greek tragedies, while the text also gives an equivalent to Fortinbras's final words: "such a sight as this / Becomes the field, but here shows much amiss" (5.2.354-5). What it subtly adds, however, is the blessing - the religious, Christian dimension lacking in the play written by a man who was notoriously distrustful of the church, but taken over by a composer who lived at a time and in a space where belief in God - the forbidden fruit - gave people strength and the hope that the horrors of a totalitarian regime might be overcome. Even such a covert blessing - a mere reference to angels - was an act of courage in a society where the practice of faith was surveyed by the secret police.

Musically, the Epilogue provides precisely the dirge that Shakespeare prescribed, "A dead march" being the stage indication after Fortinbras's speech. Going hand in hand with the blessing in the text, the sonorities of the Epilogue a modern re-contextualisation of archaic church chant - remind the listener of Paul Constantinescu's Byzantine Easter Oratorio, lending symmetry to the opera through a conclusion that matches the religious atmosphere of the chorus in the Prologue.

$$
\text { **** }
$$

However, when three American Jews adapt Romeo and Juliet into a musical, all hint at Christianity is erased. Leonard Bernstein's musical West Side Story, with lyrics by Stephen Sondheim and choreography by Jerome Robbins, premiered on Broadway in 1957. The action moves to New York in the mid50's, and the Capulets and Montagues - "Two households, both alike in dignity" (1.Prol.1) - are replaced with rival Polish and Puerto Rican gangs. Initially, the three collaborators even wanted to rewrite the plot so as to focus on the antiSemitism of the Catholic "Jets" aimed at the Jewish "Emeralds". But when they realised that the theme had been tackled before, they abandoned the project for almost five years and then resumed work to create the musical in its present form. However, Jack Gottlieb, Bernstein's former assistant, dedicated a chapter to Bernstein in his Funny, It Doesn't Sound Jewish: "Gottlieb examined specific influences from synagogue music and Yiddish songs (...) and (...) demonstrates the similarity between a traditional shofar call and the three-note 'shofar' figure 
in West Side Story" (Simeone 83). It must be noted, however, that an untrained ear does not perceive such Jewish undertones.

\section{****}

Cultural and historical barriers enjoin re-contextualisation: the English, French and Welsh verbal fun in The Merry Wives of Windsor - a type of humour that would seem inaccessible to adaptation at first glance - is metamorphosed into Germ-Italian in Salieri's Vienna. The Merry Wives sparkles with the enormous fun of, in Mrs Quickly's words, "abusing... God's patience and the King's English" (1.4.4-5), and H. J. Oliver writes of it as of "one of the most astonishing galleries of perpetrators of verbal fun that even Shakespeare ever put into a play" (4). Sir Hugh Evans, a parson, speaks with specific Welsh mistakes, converting the b's into p's, the d's into t's, and the v's into f's. Nevertheless, he confidently corrects the others.

Dr Caius, the physician, benefits from all the malicious irony aimed at Frenchmen by the English. Thus he pompously declares: "If dere be one or two, I shall make a de turd" (3.3.251) instead of the third.

A delightful addition to this panoply is Mrs. Quickly. During Shallow's Latin lesson, she is horrified to hear the declination "horum - harum - horum" (4.1.64), as she takes whoring to be a thoroughly indecorous word. When commending Mrs. Ford to Falstaff, she describes her as a "fartuous" civil modest wife, as close as she can get to "virtuous" (2.2.101.) An irresistible finishing touch is conveyed by her indignant "I detest" (1.4.156), intended to mean "I protest" - a type of verbal derailing which must have inspired Sheridan's memorable character of Mrs. Malaprop in The Rivals.

Among the many operas inspired by this play, ${ }^{1}$ Antonio Salieri's Falstaff $o$ Le Tre burle ["Falstaff or The Three Tricks"] on a libretto signed by Carlo Prospero Defranceschi, is the only one to preserve this vein and find an astute way to adapt it to the social and cultural context in which it was created, that is, the Vienna of 1799.

Verbal humour is surprisingly echoed in Salieri's opera in the scene of the embassy to Falstaff. Instead of the inexistent Mrs. Quickly, it is carried out by the primadonna, Alice Ford, as a good opportunity for her to be present on stage and sing an aria. Unexpectedly, Mrs. Ford comes to Falstaff's room disguised as a German virgin and converses with him in Germ-Italian. Eighteenth century Vienna was, linguistically at least, the most cosmopolitan city in Europe, and Salieri's audience was perfectly able to enjoy all the subtlety of this scena tedesca. In the dialogue, Falstaff makes mistakes in German, since

${ }^{1}$ The best known adaptation of this play is Giuseppe Verdi's masterpiece Falstaff (1893). 
it is a foreign language to him, but he also massacres Italian (conventionally used for English) in order to make the German girl better understand it:

\author{
Falstaff: \\ Mein Jungfer, \\ Ich sag in Confidenz: \\ Von Deutsch nix haben \\ viel Intelligenz: \\ Vor das ich dir pregieren \\ Nostra lingua du will \\ mit mich parlieren.
}

\author{
Mein Jungfer, \\ Ich sag in Confidenz: \\ Von Deutsch nix haben \\ viel Intelligenz: \\ Vor das ich dir asken \\ Our language du will \\ mit mich speaken. ${ }^{1}$
}

(Defranceschi 131)

German mostly lends its word order and affixes to Falstaff, while Italian gives the lexical and semantic core of the text (confidenza, intelligenza, pregare, nostra lingua, parlare). The reference to the English language (conveyed through Italian in the opera) is cleverly and dexterously avoided by the neutral term "nostra lingua."

In turn, the disguised Mrs. Ford feigns to speak very poor Italian, yet she also makes mistakes in German, as it is not in fact her mother tongue. ${ }^{2}$

Mrs Ford:

Ma io far molti Böcke...

But I to make many Böcke...

Voler dir... molti falli.

Mean say... many mistakes.

(Defranceschi 133)

Defranceschi is also the only librettist who attempts to preserve some of Shakespeare's bawdy through the vocabulary he selects. For instance, he could have chosen the noun sbaglio for 'mistake', but instead he chooses fallo, which also means phallus (in which interpretation the German maid would say "I do many phalluses").

When she must speak about Mrs. Slender's feelings for the knight, the disguised Mrs. Ford says:

Mrs Ford:

Ma pur per lei, mein Herr, $\quad$ As for her, mein Herr,

\footnotetext{
${ }^{1}$ All translations from Defranceschi's libretto are mine.

${ }^{2}$ There is, of course, no valid reason why Mrs. Ford, a bourgeois housewife of Windsor, should speak German. The veracity of the character is momentarily suspended for the sake of the Viennese audience that can thus enjoy a scene that is half in their own language.
} 
Aver gross infezione.

To have gross infection.

(Defranceschi 138)

Blaming it on her poor mastery of "nostra lingua", she uses the word infezione instead of affezione, thus equating Falstaff with an infectious disease. Moreover, Mrs. Quickly could easily be imagined to say that Meg has great infection for the knight, and the misuse of this word is hardly accidental, being genuinely akin to Shakespeare's deliberate language distortion.

Thus, the time and place for which the opera was composed, as well as all the social realities they implied, led to this unique translation, or rather transposition, of Shakespeare's verbal humour.

$* * *$

However, operas such as Gioacchino Rossini's Otello or Ambroise Thomas's Hamlet almost entirely replace Shakespeare's significances.

Otello takes place only in Venice. The whole economy of the play revolves around the love plot, with no hint at military pursuits or rivalries. Moreover, the character of Cassio disappears altogether (and with him Iago's envy of his lieutenancy). Desdemona's father unfathomably turns from Brabantio into Elmiro and his part grows extensively, as he is present throughout the three acts. Emilia is no longer Iago's wife (hence he can no longer be jealous), but merely Desdemona's confidante. Her role is also expanded. The reason is, no doubt, the need for vocal balance within the score, Elmiro and Emilia providing the only low ranges of the work (a bass and a mezzo-soprano respectively). Emilia is definitely akin to the Nurse in Romeo and Juliet, and indeed the whole opera tends to migrate towards the significances of that play.

As mentioned previously, the handkerchief is replaced by a letter and Cassio's dream could correspond to a "raped" lock. One way or the other, as Shaw remarks, never disappointing in his mercilessly biting comments, it is a cheap device: the plot "is a pure farce plot: that is to say, it is supported on an artificially manufactured and desperately precarious trick with a handkerchief which a chance word might upset at any moment" (Shaw 224). To top it all, in the end Otello stabs Desdemona. Illogically, she knows that Iago is dishonest, yet does not wonder at all why Roderigo's death should be a punishment to her. Equally incongruous is the finale, in which the whole court - the Doge, Elmiro and Roderigo included - are happy to pardon the exiled (!) Moor and grant him Desdemona's hand only because Iago has confessed to his treachery.

As Schmidgall puts it, "the opera's largest dollop of nonsense [is] the handling of Shakespeare's Roderigo" (307). From a weak languishing bore and a dupe easily manipulated, he turns into no less than the Doge's son and a serious love rival to Otello. The reason for this alteration is not only musical but also "historical". At the time, Barbaia's theatre in Naples boasted a peerless panoply 
of gifted tenors, which led to the uncanny (and today nightmarish) idea of casting no less than five tenors in Otello, out of which three are principals!

$$
* * *
$$

Hamlet by Ambroise Thomas is a clear instance of the syntagma that has become a truism by now: traduttore - traditore. "There is good music, there is bad music and there is... Ambroise Thomas", famous composer Emmanuel Chabrier declared with typical French irony and ambiguity (qtd. in Masson 7, my translation).

Loosely based upon the translation of Alexandre Dumas, père, Thomas's opera is constrained by the conventions of grand opéra and of the tradition of classical drama in France. It therefore preserves the five acts, but the rest is altered almost beyond all recognition. Fortinbras, Voltimand, Cornelius, Rosencrantz, Guildenstern, Osric, Bernardo, Francisco, Reynaldo, the English Ambassadors and the Clowns disappear. It starts with the coronation scene and later on Horatio and Marcellus give the news of the apparition to the Chorus that must in turn give it to Hamlet! In the following scene, however, it becomes obvious they have failed to do so, and Horatio and Marcellus have to do it themselves.

Laertes leaves to fight for his country in Norway and he entrusts his sister to Hamlet. As this is a French opera, cherchez la femme seems to be the crux of the matter, the whole weight shifts and Hamlet is far more preoccupied with love than with the Ghost's request.

We are thus spared Polonius's advice list, which would nevertheless have made good material for an aria. In fact Polonius's whole part is drastically reduced and the nice surprise is that he does not die and he will take part in his daughter's funeral procession.

The Ghost seems to point to Gertrude's adultery before his death, while the poison is poured upon the sleeping king's lip, which of course destroys the metaphor of poisonous words dropped into one's ear.

Ophelia reads a book of her own accord and Polonius is not there to guide her. Hamlet passes her by without stopping. The Queen appears, worried about her son. In a duet, Ophelia deplores the prince's coldness and wants to retreat to a nunnery! Gertrude implores her not to go, as she is her last hope for Hamlet. As she seems to be a dream mother-in-law for any woman, Ophelia obeys. of Act III.

The famous "To be or not to be" monologue is moved to the beginning

In a duet with his wife, Claudius asserts that Hamlet has lost his reason. Gertrude is afraid her son has found out the truth and thus makes it clear to the audience that she was her second husband's accomplice in the murder of her first. Hamlet joins them in a trio and informs them of the actors' arrival. He then 
sings an aberrant drinking song which, if the interpreter has any sense of discernment, he will not make cheerful, in spite of the sparkling and exuberant quality of the music in major key (B flat major).

The Mouse Trap is entirely a ballet and pantomime scene. The ballet scene was a sine qua non requirement of the Paris Opera House, an imposition which caused many unnatural plot caesuras over the years.

Claudius is unmasked and in the ensuing havoc, Hamlet urges the chorus to avenge the dead king, implying that the realisation of his guilt is general. The ensemble provides a perfect opportunity for a conventional tension-wrung Finale.

After the displaced monologue, Hamlet sees Claudius pray. The guilty king thinks he sees his brother's ghost and calls for Polonius's help! Thus Hamlet, concealed, understands that Polonius is also his uncle's accomplice.

In a trio, Gertrude informs her son that Claudius has settled his wedding with Ophelia. But, as he looks at his betrothed, the prince realises she is the traitor's ${ }^{1}$ daughter, their love is doomed, and sends her to a nunnery, which had been her wish in the first place.

Left alone with his mother, Hamlet accuses her of murder. Guilt and grief make the Queen temporarily lose her mind - which is part of the revered bel canto tradition of much-cherishes mad-scenes. Thus in this opera there are three of them, if we also count in Hamlet's drinking song. Gertrude begs for her life and the Ghost appears and reminds Hamlet to spare her.

Ophelia loses her wits because she no longer has the prince's love. Her father's death at the hands of her lover is no longer an issue since Polonius is alive and well. She only speaks to the Chorus. All the bawdy allusions are purged from this decorous scene, as nineteenth century French theatre - contrary to the general conception - abhorred sexual innuendo on stage (quite unlike the eighteenth century French novel). She says that Hamlet is her husband and that no one must believe he has forgotten her. The song she sings is not Shakespeare's. This bowdlerised and cleansed image of a happily married coupled is followed by the repetition of the "Doubt that the stars are fire" couplet (first heard in the Act 1 duet) and by Ophelia's drowning. Unrequited love resulting in madness and death are solid operatic conventions. Yet, this scene is a musical masterpiece.

The final act opens with two gravediggers who sing an unavoidable drinking song and have no contact with the other characters or with poor Yorick. Hamlet seems to know Ophelia has lost her mind. Laertes shows up unexpectedly and holds the prince accountable for his sister's state. The latter feels guilty. Reluctantly he accepts Laertes's dare to a duel, which takes place in the same graveyard, and is wounded. They both hear the funeral procession and

\footnotetext{
${ }^{1}$ Polonius has been revealed as a traitor.
} 
neither knows who is dead. Polonius, the King, the Queen and the Ghost are there too. In his grief, Hamlet remembers his pledge of revenge and the Ghost reproves him for his tardiness. Therefore the former lashes out and kills Claudius. All present exclaim: "The King!" While Hamlet replies: "No, my father's murderer!" To baffle Shakespeare's clumsy procrastination, justice is efficiently made. The Ghost pronounces the murder avenged and asks that Gertrude be sent to a convent (which seems a handy and popular solution to all wrongs). Claudius does not miss his chance to clarify that he dies damned, while his wife asks for God's forgiveness. The Ghost tells Hamlet: "Live for your people. God himself is crowning you!" (Carré and Barbier) ${ }^{1}$

This end which depicts Hamlet as the future King of Denmark is taken over from Alexandre Dumas's 1847 translation: "Since Hamlet is not guilty to the same degree as the others, he should not die the same death as the others." Four dead bodies would constitute "the most unpleasant effect." Since the Ghost appears at the beginning of the play, "it must necessarily reappear to be present at the end" (Pemble 111). Apart from a penchant for symmetry, nineteenth century French theatre reduced violence on stage to a minimum, while gore was perceived to be in bad taste. Poetic justice was also strongly desirable. Nevertheless, the happy ending is surprising, as tragedy was extremely popular in France at the time. An outraged English response to the opera made Thomas write an alternative ending, in which the Ghost is absent. Distraught at seeing Ophelia's lifeless body, Hamlet kills Claudius and then kills himself.

This account of Ambroise Thomas's work clearly shows the influence of tradition and convention upon translation and adaptation. The sacrosanct law of decorum and political correctness avant la lettre banned violent death as well as bawdiness from the French stage. Likewise, vocal balance in the opera required two relatively proportionate couples: Hamlet and Ophelia (baritone and soprano) versus Claudius and Gertrude (bass and mezzo.) Therefore, the prince's part is significantly reduced, while the others are substantially augmented.

$$
* * *
$$

After so many operatic adaptations of Shakespeare, Porter's 1948 musical Kiss Me, Kate, a musical written by Samuel and Bella Spewack with music and lyrics by Cole Porter, comes as a highly original instance. It rewrites The Taming of the Shrew in a postmodernist script avant la lettre devised by Samuel and Bella Spewack, which features the cast of a theatre company on- and off-stage. This is a technique that will flourish more than thirty years later with works such as the 1981 film after Flowles's The French Lieutenant's Woman directed by Karel Reisz, adapted by playwright Harold Pinter and starring Meryl Streep and

\footnotetext{
${ }^{1}$ All translations from Carré and Barbier's libretto are mine.
} 
Jeremy Irons. The music score is by Carl Davis and the cinematography by Freddie Francis.

Another illustration of this technique is Noises Off - a 1982 play by the English playwright Michael Frayn. He got the idea in 1970 when watching from the wings a performance of The Two of Us, a farce that he had written for Lynn Redgrave. He said, "It was funnier from behind than in front, and I thought that one day I must write a farce from behind" (qtd. in Mehlman). The embryo of this work was a short-lived one-act play called Exits, written and performed in 1977. At the request of his associate, Michael Codron, Frayn expanded it into the fullfledged version of Noises Off. The play takes its title from the theatrical stage direction indicating sounds coming from offstage and was adapted for the screen by Marty Kaplan in a delightful film directed by Peter Bogdanovich, and starring Carol Burnett, Michael Caine, Christopher Reeve and others in 1992.

Much earlier, Kiss Me, Kate was inspired by the on-stage/off-stage battling of husband-and-wife actors Alfred Lunt and Lynn Fontanne during their 1935 production of The Taming of the Shrew, witnessed by future Broadway producer Arnold Saint-Subber. In 1947 he asked the Spewacks (undergoing their own marital troubles at the time) to write the script. The screenplay of the famous 1953 MGM film was written by Dorothy Kingsley. The plot is a mise en abyme, since the divorced couple of actors, Lilli Vanessi and Fred Graham, have the same relationship as Kate and Petruchio in the play. The text is a meta-script too, since Cole Porter is a character in the musical who grants the auditions in Act I, while Alfred Lunt and Lynn Fontanne, who inspired the plot, are also mentioned.

Shakespeare was very fond of the play within a play technique. Here we are confronted with a musical within a musical or... within a film, since at least four films were made after the Broadway show, the most famous of which is the 1953 one featuring Howard Keel and Kathryn Grayson (and the fact that she is a real Kate gives a triple turn to the mise an abyme). Dorothy Kingsley's screenplay was nominated for a Writers' Guild of America Award. The film came out fourteen years before Franco Zeffirelli's famous version of The Taming of the Shrew starring Elizabeth Taylor and Richard Burton, and I think that the physical similarity between the actors cannot be accidental and that the great Italian director must have been inspired by the American musical film.

The play is re-contextualised so as to fit the realities of the United States in the 1940's. There are gangsters ready to beat a debtor up for an IOU, but the arch-gangster ends up shot, the shooting is heard over the phone and the change rendered by the public telephone is a slug instead of a coin - an instance of tongue-in-cheek paranormal action.

Some of the text uttered on stage is Shakespeare's, and it is seamlessly connected with the text of the script. Most of the music is not set to Shakespeare's text, but to lyrics by Porter. One exception is Petruchio's entrance 
aria, whose first two lines are "I come to wive it wealthily in Padua; / If wealthily, then happily in Padua" (1.2.74-75).

The dance is in pure Hollywood style, and the tap dance is not only an element of choreography, but of music too, since the aluminium taps also function as percussion instruments.

\section{$* * *$}

This article has made a cursory presentation of opera and musical theatre adaptations of Shakespeare's plays, attempting to demonstrate that the original text can be re-read, re-written or re-contextualised in almost all conceivable forms, even as far as being utterly replaced. But remediation compensates for these "transgressions", finding new resources of inspiration that lend new significance, value and richness to the ensuing musical work, and allowing the audience to discover new valences in the Bard's refashioned opuses.

\section{Works Cited}

Bentoiu, Pascal. Libretto. Hamlet (performance programme). Bucharest: Opera Română. 1975. 11-26. Print.

Bolter, Jay David and Richard Grusin. Remediation. Understanding New Media. Cambridge, Massachusetts: MIT Press. 2000. Print.

Carré, Michel and Jules Barbier. Libretto to Hamlet by Ambroise Thomas. Web. <http://www.operone.de/libretto/thomhafr.html>. 15 Oct. 2016.

Defranceschi, Carlo Prospero. Libretto to Antonio Salieri - Falstaff. Canto e piano. Revisione Eva Riccioli. Florence: Edizioni musicali Otos. 1969. Print.

Greenblatt, Stephen. Will in the World. How Shakespeare Became Shakespeare. London: Pimlico. 2005. Print.

Kingsley, Dorothy. Screenplay to Kiss Me, Kate - 1953 MGM film (based on Samuel and Bella Spewack's book to the 1948 Broadway show). Web. <http://www.script-o-rama.com/movie_scripts/k/kiss-me-kate-scripttranscript.html>. 20 Oct. 2016.

Masson, Georges: Ambroise Thomas - un compositeur lyrique au XIX siècle. Metz: Editions Serpenoise. 1996.

Mehlman, Barbara K. "Noises Off." Rev. of Noises Off by Michael Frayn. CurtainUp. Web. <http://www.curtainup.com/noisesoff.html>. 17 Oct. 2016.

Oliver, H. J. Introduction to The Merry Wives of Windsor. The Arden Shakespeare. London: Methuen \& Co Ltd. 1971. Print.

Pemble, John. Shakespeare in Paris: How the Bard Conquered France. London: Hambledon and London. 2005. Print.

Porter, Cole. Lyrics to Kiss Me, Kate. Web. <https://www.allmusicals.com/k/kissmekate.htm>; $<$ http://www.songlyrics.com/kiss-me-kate-lyrics/>; <http://www.allthelyrics.com/lyrics/kiss_me_kate_soundtrack>. 20 Oct. 2016. 
Schmidgall, Gary. Shakespeare and Opera. New York \& Oxford: Oxford University Press, 1990.

Shakespeare, William. A Midsummer Night's Dream. The Oxford Shakespeare. Oxford World's Classics. Stanley Wells (gen. ed.). Peter Holland (ed.). Oxford: Oxford University Press. 2008. Print.

------- Hamlet. The Oxford Shakespeare. Oxford World's Classics. Stanley Wells (gen. ed.). G. R. Hibbard (ed.) Oxford: Oxford University Press. 2008. Print.

------ Othello. The Oxford Shakespeare. Oxford World's Classics. Stanley Wells (gen. ed.). Michael Neill (ed.). Oxford: Oxford University Press. 2008. Print.

------- Romeo and Juliet. The Oxford Shakespeare. Oxford World's Classics. Stanley Wells (gen. ed.). Jill L. Levenson (ed.). Oxford: Oxford University Press. 2008. Print.

The Merry Wives of Windsor. The Oxford Shakespeare. Oxford World's Classics. Stanley Wells (gen. ed.). T. W. Craik (ed.). Oxford: Oxford University Press. 1998. Print.

------- The Taming of the Shrew. The Oxford Shakespeare. Oxford World's Classics. Stanley Wells (gen. ed.). H. J. Oliver (ed.) Oxford: Oxford University Press. 2008. Print.

Shaw, Bernard. "A Word More.” Anglo-Saxon Review. Ed. Louis Crompton. March 1901. The Great Composers - Reviews and Bombardments. Berkeley: University of California Press. 1978. Print.

Simeone, Nigel. Leonard Berstein: West Side Story. Farnham: Ashgate. 2009. Print. 